\title{
Aceh Islamic Society (Beliefs in Animism and Dynamism)
}

\author{
Ridwan Muhammad Hasan ${ }^{1}$, Iskandar Ibrahim², Saifuddin Dhuhri ${ }^{2}$ \\ ${ }^{1}$ Lecturer in Islamic Communication Faculty, Islamic University of Ar-Raniry (UIN Ar-Raniry), \\ Banda Aceh, Indonesia, \\ ${ }^{2}$ Lecturer in Islamic Communication Faculty, Islamic State Institute of Religion, (IAIN Lhokseumawe), \\ North Aceh, Indonesia \\ email: ridwanhasan45@gmail.com
}

\begin{abstract}
The people of Acheh society so immersed in the customary beliefs, traditions and cultures of Hinduism, and belief in large wooden staples such as, banyan trees and ketapang trees, as well as trustworthy objects possessing supernatural powers of animism and dynamism. They are also cling to the teachings of religion that have been abandoned by the former, even though those who bring the teachings are not derived from Islam, indirectly the belief, can form personal in everyday social that is not very memorable. In some parts of the Acheh community who live in rural areas up to now, practice the customs and culture of the tahayul rather than Hindu relics such as, the practice of heresy, superstition and khurafat and has become a practice in its daily that is difficult to be left.
\end{abstract}

Keywords: Aceh; society; animism; dinamism

\section{Introduction}

Nanggroe Aceh Darussalam (NAD) was located on the north of the Sumatra Island. This territory also was the entrance and left the Malacca Strait to the Hindi Ocean. The history noted down that this territory was to be the Islam kingdom in South-East Asia in the age 16 and 17 B.C. The Aceh community was the community that like that fanatical the current and the traditional belief, the tradition and the Hindu teaching culture, as well as the belief in the big tree trunk like, the banyan tree and the ketapang tree, as well as objects that could be trusted had the strength ghaib animism and the dynamism.

The Aceh community was the community that like that fanatical with the current and the traditional belief, the tradition and the Hindu teaching culture, They were also still gripping tight to the religious teaching that was left by the previous person, although that carried this teaching not came from the Islam religion, for this reason in a manner indirectly this belief, could form private in life every day that very much did not make an impression.

In a community's Aceh part that lives in the countryside territory up to now, was still carrying out the tradition and the culture that were confused than the legacy of the Hindu teaching like, the good deeds heresy, superstition and superstition and has become a good deeds in his days that were difficult to left. In general, Aceh traditional community still belief and trusted that the genie's kind in various forms like jen apui, the burong, geunteut, beunot and burong tujoh. They also still trusted that the person's soul who died in the situation was very frightening as being killed, died was bloody, died sank, died fell from the tree trunk 
etcetera, will change, into the ghost. In the life all day long the community also trusted that the bad person all his life and when dying his spirit will change in the pig kind or the monkey that left his grave. On the other hand, too devout person will become the sacred person and changed in the form of the tiger or the good snake his nature that was trusted could protect the typical village in area the grave.

In the everyday life that the community Aceh habit very much obeyed in undertaking the religious ceremony, in fact very fanatical towards his religion. This gave the picture that Islam had been built and gotten a foothold firm in him the Aceh community. Although, not all the Aceh communities carried out all the Islam teachings that were true and pure. But, the Islam religion became hereditary than his ancestors, then if being born then automatically has become a Muslim, because his parents became a Muslim before. As for, the matter in fact that happened, that the Aceh community in a part of him did not yet understand the Islam teaching. The intention from philosophy above was to say, the life of Aceh community since the past based on and held on tight to the law, the tradition and customs. Traditional law also very much played the important role in the formation of the character, the pattern of thoughts in the change in the social structure in the Aceh community. The law also often gave the emphasis to ethics, animism in the Islamic values the life all day long that was as true like one of the methods path for mystics to follow, in order to be able to clean the spirit who was contaminated with the sin in the past and temporary period mysticism up to now still also are carried out like naksyabandiyat, salek seunaga, wahdat wujud shape and this current already many of his followers in the Aceh community in the period beforehand and now this possibly already few of his followers.

Moreover, the social change in piety also could affect the corner of the view in having the fellow community relationship, because the Aceh community consisted than various groups and the dimension of the culture, even various nations that lived in the Aceh land. According to the note in culture of that the original Aceh inhabitants before embracing the Islam religion came than various nations and the group that came like Arabian, Persia, China, India and Portuguese. Then in an associated manner and mixed the culture happened one mixed in a belief and the unique culture, in being religious good that was positive like that was negative. According to the belief concerning Wednesday that was last in the Safar month (on Rabu Abeuh), his aim of these good deeds was to expel the bad spirit, according to the understanding of the community that could destroy in the community. In article information that above that, Allah ordered his group to do the good deeds that was good from everything that was easy and not causes problems for but also Allah ordered so that avoided than people ignorant good deeds.

Nevertheless, a Muslim scholar not yet on the whole to make a change or eliminated than the good deeds superstition and through to the understanding of the pure belief that as being hoped for. As for, the good deeds was carried out by him that belief, might cause intercession if being carried out and causing the disadvantage if being left. Concerning the implementation of this matter, in the Aceh area is as the tradition and the annual tradition, up to now still many good deeds that in a manner indirectly still are carried out by the Aceh community generally. However, the Aceh community that was not freed than managing of the government like, the Council of scholer and an agency of the fatwa body to be able to give and accept the opinion also the view than the Aceh community that was the same his function like, the Council of Scholer Indonesia. 
But, there was a little difference between him concerning the implementation of the work program that more headed to the application or pay attention to directly touched and supported the implementation of Islamic canon law, good in the official of the government want also in the field.

\section{Review of Literature}

At the start the entry of the Islam teaching to the Aceh area was to be mixed between an element or was affected and the social life, the Indian cultural tradition in typical him to the territory of Gujarat India. Up to now did not yet have his explanation concerning the entry of the Islam religious teaching, but made a conclusion that most almost in the fact and the data in the field that could support the opinion than results of his study that was undertaken.

The beginning of the entry of the Islam teaching to the Aceh area, clearly to analyze and was studied concerning the beginning of the entry of the Islam teaching to Indonesia. If the being seen in Aceh regional geography in west this island part, then gave a picture or the very clear and clear explanation that natural the Islam teaching entered and his arrival went through the Aceh area.

As in the history seminar that the entry of the Islam religious teaching to Indonesia that was held by private enterprises circle, in the Medan city to the annals, 17-23 Mac 1963, then in this seminar agenda that could be taken by several conclusions in part;

i. $\quad$ The Islam teaching entered Indonesia in the age to 1 (one) Hijriah.

ii. The Aceh area was the first area accepted the Islam teaching in the Sumatran coast but also after the entry of the Islam teaching then the Islam king that at first was in the Aceh area.

iii. The arrival of the Islam teaching could to Indonesia enliven the community and received some culture that was high.

In the process of development the Islam teaching to the Indonesian archipelago if being seen in the view of and the historians were met by several difference concerning this matter. But, the researcher wanted to take a conclusion that in this process could in make to two stages; First, from the age to 7-13 of Masehi. In general him that took this role was people who came from the Arabian Land. Secondly, from the age 13 Masehi. The henceforth that took as the disseminator of the Islam teaching but also as the preachers and the trader from India, Persia and Arabian.

Hurgronje that look to one of his views to Gujarat, India that was based on him, according to him was very much strong to give a conclusion in part;

i. The existence of trade relations between the Hindu person and Indonesians before Islam and these trade relations were continued after the Hindu person embraced the Islam religion.

ii. Gujarat was one of his most important ports where leaving of the merchant Hindu like also Islam to Indonesia.

iii. Gravestone stones and the most important grave in Indonesia were artificial that had scepters and was put from Gujarat.

iv. The names that were buried that was the kings that used title the Shah from Parsi or the other name that approached the Persian names or India. 
v. The customs and traditions adjustment and the tradition with a country like, Indonesia and India that through to until now be still could be seen in the everyday life in the Aceh area.

vi. The existence of the understanding of the Syi'sah current and Sect Wahdatul Wujud in mysticism knowledge in Indonesia.

vii. The inscription (the long text) eldest about Islam that was received in Sumatra (Aceh) gave the picture of relations between Sumatra and Gujarat.

According to the Snuck Hurgronje view, had the influence that was very big against the West and influential historians also towards the history in Indonesia. The Gujarat theory in general him, gave explanation, the Islam teaching entered the Indonesian Archipelago in the $13^{\text {th }}$ age.

This opinion was based on proof that the existence of Sultan gravestone, that stone is the first than the kingdom of the Pase Ocean (Aceh), namely Sultan Malikussaleh that died in the year 1297. The opinion that said that the gravestone stone that was gotten in this Pase had the characteristics of art built than the Hindu teaching with these findings increasingly strengthened that Theory Gujarat (India) that was truer.

\section{Discussion}

Long before the birth of the Islam teaching has often come people from the Indian country that looked for the residence (the colonization), in Java and the islands that were located around it that carried civilization that was broadcasted by him in these places, after religious Hindu people entered Islam. However, people Hindu that embraced this Islam teaching et cetera continued the life road that has been followed beforehand. The Islam teaching in the Aceh area if being seen in the previous period, was gotten by several teachings that were accepted by the community at the time, up to now had several Islam teachings that still were remaining in the community.

Based on principles in the history the area of Aceh Besar the border of the Polyclinic time had been affected by the HinduMahayana religion and the Islam religion entered there through with two first roads from Pase through the child Sultan Malik Al Zahir, the two that possibly was coming from the Iraq country, Yemen and India, while these countries have been gotten there thinking Syiahand in general him the Arabian west country very was affected by Zaidiyah one of the Sect Syiah understandings and up to now still developing and this was a clear proof that these Arabians who brought the Syiah teaching until arriving at Aceh (Indonesia).

The community Islam Aceh up to now is not freed than the influence of the matter of elements of the belief, that has joined with the spirit to good deed in the life all day long, now to eliminate and through to the purification stage of the community belief Islam Aceh possibly needed the period that many and was supported with the government co-operation in purification of this belief. If being seen from the history was noted that the background of the entry of the Islam teaching also came from the Indian country that majority the inhabitants in this area that followed the Hindu Tantri Bhirawa teaching.

Then this belief situation was formed an element of the belief that has been mixed between the Hindu teaching with the Islam teaching, afterwards that in the long run this Islam teaching has become a mix between a foreign culture with the culture that entered the Aceh 
area, then made a good deeds until becoming a belief that was close to the Hindu teaching good deeds, that without being was founded from the Islam teaching that was true.

In the period before the arrival of the Islam teaching in the Aceh area the community was again following an element of the animism belief and the dynamism or still regarded had the strength that was hidden in the inanimate object and to the element of the strength mysterious in all the places that might help them in the period to need help for all the needs.

But, the element of the belief in animism and the dynamism that did not remain old in the Aceh community and not old afterwards until the Islam teaching entered the Aceh area that went through the route from Gujarat that at first the first community of the sea coast accepted this Islam teaching and in the following stage just the community that lived in the countryside territory that in majority very much thick with the element of the belief in the inanimate object and ghaib that up to now, still is remaining and leaving a trace in understanding of the Aceh community that very much to be difficult to be changed and was purified to the Islam teaching actual.

In the Aceh community that still was gotten various elements of the Hindu religious belief up to now, still also are having results, in fact was carried out in the life of the community that remained in the regency region of Aceh North and even in the area the Lhokseumawe Town although, resulting from than the influence from the Hindu religious teaching personally, in fact this element has entered the Islam good deeds of the belief of the community's religion that lived in the hinterland.

In this belief indeed might not have been separated again, and the element and in this good deeds very much dangerous from the aspect of the community belief in general him and this indeed should has been current in the social circle Islam Aceh.

\section{Conclusion}

The Aceh regional community also was the community that still often very much was carrying out various sorts and customs of the traditional ceremony in the belief. In the tradition and the community tradition that the celebration ceremony that was carried out began since from the birth day, as the ceremony tradition welcomed the baby, shaved the baby hair, doctrine and descended the land, and afterwards was accompanied with various traditions and abstention banned that was begun from before was born until giving birth in the period forty four days and the tradition not all of them the person carry out again until now this with the social change and the culture then abstention banned this often had not been left and carried out again by a person part.

The customs and traditions ceremony of marriage also was a good deeds that must be carried out in the Aceh community, like beginning with the agenda to apply that was accompanied with engagement betel and even so with the wedding that in the Aceh community also was known by being married hanged and was married came home continued as that happened in general him in the community up to now.

The ceremony customs and traditions of the marriage in the community tradition in a part was also that based on principles than the tradition and the Hindu culture of the religious teaching that left in the period beforehand, up to now also still remained and still also was carried out by the community in the matter of the party agenda of marriage that a community part carried out the Hindu tradition of the tradition of the religious teaching, As stepping on 
the egg before beginning him the agenda, bridegroom travel by above the decorate the bed of the newlyweds to be sharp.

The tradition in the death ceremony in the community were has been as the habit that must be carried out if having his resident who died then the families and the community went along as well as to make a ceremony bury together the community. In carry out and commemorating his funeral ceremony this body that was begun from the beginning through to by being finished.

Then entered in the first night, the night to seven, the $30^{\text {th }}$ night, the forty fourth night and the hundredth night in the habit always will be carried out the ceremonial meal and songs of praise and the family that still experiences the disaster must to prepare food and the drink for the community members who came to carry out the songs of praise agenda. Then the tradition and this tradition up to now still also are carried out by the community in the Aceh territory and now devout, the Muslim scholar, or Ustad went along as well as in carry out and supporting the implementation of this agenda.

\section{Reference}

Abi al-Hasan, Ali bin Muhammad Habib al-Mawardi al-Basri. (1994). al-Hawi al-Kabir: Fi Fiqh Madhhāb al-Imām as-Shafi’i. Bairūt: Dār al-Kitāb al'lmiyat.

Al-Baghwi, al-Imam Abi Muhammad al-Husain bin Masud bin Muhammad bin Fira' (1997). al-Tahzib Fi Fiqh al-Imām as-Shāfi'i. Bayrūt: Dār al-Kitāb al- '1lmiyat.

Al-Hanbali Syaikh Mansur bin Yunus al-Bahauti. (1997). Qasyafūl Qanā.' Bayrūt: Dār alKitāb al-'1lmiyat. Juz. 2.

Al-Attas, Syed Muhammad Naguib. (1966). Raniri and the Wujudiyah of $17^{\text {th }}$ century Aceh. Singapore.

Al-Attas, Syed Muhammad Naguib. (1969). Preliminery Statement on a General Theory of the Islamization of the Islamization of the Malay Indonesian Archipelago. Kuala Lumpur: Dewan Bahasa dan Pustaka.

Al-Attas, Syed Muhammad Naguib. (1970). The Mysticism of Hamzah Fansuri. Kuala Lumpur: University of Malaya Press.

Banton, Michael.(ed). (1977). Anthropological Approch To The Study of Religion. London: Tavistok Publication.

Bellah, Robert N. (1953). Religion: The Sociology of Religion. dalam David L.Sills (ed). New York: The Macmilan Company. Vol.14.

Berger, P.L. (1995). Religion and Modernity. Jakarta: For Jakarta Conference.

Boland, B. (1970). The Struggle of Islam in Modern Indonesia. Den Haag: Martinus Nijhoff.

Edward B. Tylor. (1871). Primitive Culture: Researches into the Devolopment of Mythology, Philosophy, Religion, Language, art and Custom. New york: Henry Holt \& Co.

Gill, Sam D. (1982). Beyond The Primitive. New Jersey: Prentice-Hall, Inc.

Harper, Edward B. (ed). (1964). Religion in South Asia. USA: University Washington Press.

Hedayatullah, M. (1977). Kabir. The Apostle of Hindu-Muslim Unity. New Delhi: Motilal Banarsidass.

Hurgronje, Snouck. (1970). Mekka in the Latter Part of the $19^{\text {th }}$ Century. Leiden: E.J.Brill.

James, William. (1960). The Varieties of Religious Experience. New York: A Mentor Book. The New American Library. 
Karl, G. Heider. (2000). Seeing Anthropology: Cultural Anthropology Through Film. USA: Allyn and Bacon.

Loeb, Edwin. L,. (1972). Sumatra It's History and People. Kuala Lumpur: Oxford University Press.

Lowie, Robert H. (1959). Primitive Religion. New York: Liveright Publishing Company.

Malinowski, Bronislaw. (1954). Magic, Science and Religion. New York: Doubleday Anchor edition. Doubleday and Company. Inc.

Nicholson, R. A. (1921). Studies in Islamic Mysticism. London: Cambridge University Press.

Peters, Rudolph. (1979). Islam and Colonialism. The Hague: Mouton.

Olivelle, Patrick. (1992). Samyasa Upanisad Hindu Scriptures On Ascenticism and Denunciation. New York: Oxford University Press.

Rizvi, S. (1983). A History of Sufism in India. New Delhi: Munshiram Manoharlat Pvt. Ltd.Vol.2.

Schrieke, B. (1960). Indonesia Sociological Studies. The Haque and Bandung: W.Van Hoeve Ltd. part II.

Turner, B. S. (1991). Religion and Social Theory. London-Nebury Park-New Delhi: SAGE Publications.

Wach, Joachim. (1947). Sociology of Religion. London: Kegan Paul. Trench. Trubner \& Co. Ltd.

Van, Vollehoven. (1986). On Indonesian Adat Law. Holland: The Hague, Martinus Nijhoff.

Zuhaili, Wahbah. (1997). al-Figh al-Islami wa'dilatuhu. Bairūt: Dār al-Fikr al-Mu'āsir. 